This is an electronic reprint of the original article. This reprint may differ from the original in pagination and typographic detail.

Author(s): Jokinen, Elina; Vaarala, Heidi

Title: $\quad$ From canon to chaos management : blogging as a learning tool in a modern Finnish literature course

Year: $\quad 2015$

Version:

Please cite the original version:

Jokinen, E., \& Vaarala, H. (2015). From canon to chaos management : blogging as a learning tool in a modern Finnish literature course. In J. Jalkanen, E. Jokinen, \& P. Taalas (Eds.), Voices of pedagogical development : expanding, enhancing and exploring higher education language learning (pp. 241-278). Research-publishing.net. https://doi.org/10.14705/rpnet.2015.000295

All material supplied via JYX is protected by copyright and other intellectual property rights, and duplication or sale of all or part of any of the repository collections is not permitted, except that material may be duplicated by you for your research use or educational purposes in electronic or print form. You must obtain permission for any other use. Electronic or print copies may not be offered, whether for sale or otherwise to anyone who is not an authorised user. 


\title{
12 From canon to chaos management: blogging as a learning tool in a modern Finnish literature course
}

\author{
Elina Jokinen ${ }^{1}$ and Heidi Vaarala ${ }^{2}$
}

\section{Abstract}

$\mathrm{T}$ his article is based on the teaching experiment implemented in summer 2013 in a modern Finnish literature course organised by the Centre for International Mobility (CIMO) and the University of Jyväskylä Language Centre. In order to break away from the traditional conception of literature and text, students' independent blogging was chosen as the final course assignment instead of a traditional final project. Our aim has been to determine what blogging as an activity can add to second-language learning (i.e. learning the language in a country where it is spoken as a native language) in the context of modern Finnish literature. Our special interest is how new learning environments and approaches broaden the conception of literature held by students of Finnish as a foreign language. The 22 participants of the modern literature course were university students from different European countries. They had studied Finnish language and literature in their own countries, in other words, Finnish as a foreign language. The focus of this article is on the blogging process, which we observe from the perspective of process stages as well as student output. The article demonstrates that a teaching method that opens up new learning environments and learning modes - such as blogging contributes to broadening students' conception of literature and is particularly suitable for analysing phenomena in modern literature.

Keywords: second language learning, modern literature, social media, new writing.

\footnotetext{
1. Language Centre, University of Jyväskylä, Finland; elina.k.jokinen@jyu.fi

2. Centre for Applied Language Studies, University of Jyväskylä, Finland; heidi.vaarala@jyu.fi

How to cite this chapter: Jokinen, E., \& Vaarala, H. (2015). From canon to chaos management: blogging as a learning tool in a modern Finnish literature course. In J. Jalkanen, E. Jokinen, \& P. Taalas (Eds), Voices of pedagogical development - Expanding, enhancing and exploring higher education language learning (pp. 241-278). Dublin: Research-publishing.net. doi:10.14705/rpnet.2015.000295
} 


\section{Introduction}

Students study Finnish language and culture at about a hundred universities in over thirty countries. For these university students, the Centre for International Mobility (CIMO) offers a special course on modern Finnish literature. The objective of the course is to deepen the participants' knowledge and understanding of modern literature, to make them reflect on the main characteristics of modern literature and to enhance their language skills in a genuine environment. The first course was provided in 2012 by the University of Helsinki; in 2013 and 2014 the organiser was the University of Jyväskylä Language Centre. This article is based on the teaching experiment implemented in the modern literature course of summer 2013 in Jyväskylä.

The 22 participants of the modern literature course were university students from different European countries. They were students of Finnish as either a major or minor subject at universities in Russia, Hungary, Poland, the Czech Republic, Denmark, Estonia, Latvia, Lithuania and Germany. Four of the participants were men and 18 women. According to the Common European Frame of Reference for Languages, their language proficiency levels varied between B2 and C1. In other words, everyone's language skills were at least at a good average level. At this proficiency level, language users understand speech and different texts, are able to produce texts, and speak good Finnish.

In the pre-assignment and initial interview, students described their own conceptions of literature. As the course started, their conceptions of Finnish literature seemed to be traditional, with a National Romantic emphasis: they were familiar with the national literary canon, and many of them were able to name the classics of Finnish literature history. Literature published in the 1990s and 2000s was occasionally named.

The course was implemented by integrating thematic entities with blogging. The main thematic contents were nature, fantasy, humour, comic strips, multicultural literature, the various forms of modern prose, and children's and young adult literature. In addition, the characteristics of the Finnish literature institution, 
such as modern writers' different roles and their status on the book market, were also analysed in the joint meetings.

Independent blog writing was chosen as the course assignment instead of the final project traditionally used in summer courses. This was done because the participants found that writing a long report in three weeks would have made the course too fast-paced. However, we do not deal here with the problematics of the blog concept. Blog here refers to a webpage written in diary format or otherwise chronologically, whose posts are closely related to the author's personal life or are of special interest to the author (e.g. Jalkanen \& Pudas 2013).

In this article we explore the significance of blogging for broadening learners' conception of literature and strengthening their language proficiency. Our principal research question is: What can blogging as an activity add to secondlanguage learning in the context of Finnish contemporary literature? Our special interest is how new learning environments and approaches can broaden the literature conception of students of Finnish as a foreign language.

The relationship between learners of Finnish as a foreign or second language and modern Finnish literature has been studied relatively little from a pedagogical perspective. This is true even though introducing Finnish literature is an important part of teaching in nearly all units in the world in which Finnish is taught. Internationally, literature has been handled from a variety of perspectives in the context of language teaching. The following are recent examples from the 2000s, from both Finland and abroad. The Journal of Literature in Language Teaching has published articles on using literature in the context of second/ foreign language teaching, for example, about audio books as a tool for secondlanguage learning (Husson Isozaki 2014). Another interesting study reveals that literature circles offer students opportunities for meaningful and motivating literature discussions (Myonghee 2004). Hvistendahl (2000) has studied the role of literature in immigrant instruction, specifically how the integration of immigrant students into Norwegian society was promoted through discussions on the classics of Norwegian literature. In Vaarala (2009), the ways in which advanced learners of Finnish understand and interpret Finnish literary texts have 
been examined. Apart from this, there have mainly been empirical descriptions of the different ways of teaching Finnish literature for both university students studying Finnish outside of Finland and for learners of Finnish as a second language in Finland (Malm 2006; Mela \& Mikkonen 2007; Parente-Čapková 2009). The topic has also been addressed in a number of master's theses (e.g. Lounavaara 2004; Smolander 2012). Furthermore, in the national core curriculum for basic education (Perusopetuksen opetussuunnitelman perusteet 2014), literature is more visible in the instruction of Finnish as a second language - in both the subject name and its contents. The present article provides new research data for this research gap as well as presents a viable pedagogical approach for deepening students' knowledge of Finnish literature from the 2000s.

The data for our study comprise the diverse material collected during the teaching experiment: all students' written outputs and our observations on the group's activities. The most significant texts are the students' pre-assignments, the blog texts written during the course, and their feedback on the course. Due to the approach and limited scope of this article, we concentrate on the blogging process, observing it from the perspective of process stages and student output.

For the blogging task - presented in more detail in Section 2 - the students wrote three blog posts on a literary topic of their choosing on a shared online learning platform. We proceeded by looking for answers to the following questions in (a) students' blog posts and comments and (b) the notes we made on their working process:

- How do students act when they work on the blogging task? What actually happens?

- What forms of activity does each pair have in the blogging?

- What dimensions does blogging offer for work?

- What choices do students make in order to demonstrate their expertise and competence in this learning task?

The primary focus of examination was student activity. After analysing the data, we look at blogging through four stages that are loosely based on the model 
of inquiry-based learning. We present and examine in more detail the working processes of three blogger teams.

This study assumes an ethnographic approach as part of its methodology. The aim is to understand and describe the subject holistically and to observe people and the environment in a multifaceted way. Rantala (2006), among others, suggests that observing also implies physical presence in people's environments and concrete interaction situations with the participants in the study. We are personally present in the study as researchers who create meanings but, as the two teachers of the course, we are also part of the group we analyse. One of us has a background in literary research (Jokinen 2010) and written communication, the other has studied how learners of Finnish interpret and understand literature (Vaarala 2009) and taught Finnish both as a second and a foreign language.

\section{Background of the teaching experiment: how to teach \#literature?}

Until a few decades ago, literature teaching in schools and universities was dominated by the literary canon that serves the purposes of classical education (Ahvenjärvi \& Kirstinä 2013). In practice, literature education meant presenting the major classics of domestic literature and so-called national writers, in addition to reading text excerpts.

Assigning value to literature and naming significant national pieces of work was - at least in principle - possible as long as the amount of published literature was somehow manageable and the literary elite shared an idea of what was counted as high or elite literature (Niemi 2010). However, this is not the case anymore. In the 2010s, the literary canon has been replaced by chaos: the amount of published literature has exploded (Ekholm \& Repo 2010; Jokinen 2010), and literary researchers do not even agree on what is meant by literature, let alone how its different manifestations should be valued (Jokinen 2010; Lehtonen 2001). On the other hand, the ubiquity of technology has 
changed our conceptions of both reading and writing (Ekholm \& Repo 2010; Saarinen, Joensuu \& Koskimaa 2003).

Instead of aesthetic schools or ideological groups, modern literature seems to be defined by a new independence of time and place (Lehtonen 2001), the creation of a meaning network through, for instance, sound, image, videos, different visual elements and hyperlinks. In other words, this modern conception is a break from the traditional idea of text. As a whole, the role of literature in the thoroughly media-integrated culture of the 2010 s is anything but unambiguous.

'The book is now \#thebook' - this lightly provocative statement comes from the website kirja.fi, launched in 2014 by Finland's largest publishers. In reality, the literary taste and reading habits of the general public change slowly, which is demonstrated, for example, by the fact that e-books accounted for less than one percent of overall literature sales in Finland in 2014 (The Finnish Book Publishers Association 2015). Nevertheless, it is clear that the internet and particularly social media shape our social, technological and cultural practices related to reading (Kallionpää 2014a, 2014b). In our daily textual practices, in how we read and write, the change has already taken place: reading linear texts on paper is more and more uncommon, and writing rarely involves scribbling text on paper (e.g. Coiro, Knobel, Lankshear \& Leu 2014; Jenkins, Ford \& Green 2013; Taipale 2013).

The broad spectrum of texts and styles in modern literature is most typically structured (e.g. in general upper secondary school textbooks) using the concept of postmodern literature. However, the most typical characteristic of postmodern literature paradoxically seems to be precisely the avoidance of definitions: in an upper secondary school textbook, the most recent literature is aptly described as 'constantly moving carnival of diversity' and the works as 'luscious constructions, often built of intertextual loans and different historical and fictive elements' (in Hakulinen, Kivelä \& Ranta 2006). These kinds of definitions are challenging to adopt - and understand - for anyone. For non-Finnish students of Finnish language and literature, tracing these intertextual loans and fictive elements is particularly demanding. 
It is clear that when literature changes, literature education must look for new forms as well. For teachers, modern literature has become \#literature. In this new form, a text is no longer just a book filled with writing. Instead, \#literature is a phenomenon encompassing the entire discussion around a text and all the forms it takes, where a text's images, videos, links and strings of special characters, such as smileys, are all integral parts of it. These new elements have transformed reading and writing so that they no longer occur between the individual and the text only but are connected to various new activities, such as designing and producing videos and integrating them into the text. Indeed, reading and writing can now be discussed as social activities that are more than cognition occurring inside one individual's head.

Just like in the Finnish school context, a typical approach in teaching literature for learners of Finnish as a second or foreign language has involved concentrating on the various phases, trends and classics of literary history (e.g. Staršova 2007). When designing this modern literature course, we wanted to look beyond the canon and devote ourselves to enhancing students' abilities to master the 'chaos of modern literature'.

Because of modern literature's chaotic nature, with its dynamic themes and forms, we decided not to offer any ready-made explanation or model of what modern literature is. Instead, a central starting point in designing the course was our interest in modern literature as a phenomenon - its manifold texts often detached from the traditional book form, but also the functioning of the literary institution and the field of Finnish literature. The aim of this approach was to promote understanding and enable a conceptual change in students' thinking not so much to increase the amount of scattered knowledge.

Similarly, because of the changed conception of text and the technologisation and multimodality of literature, we found it important to emphasise learningby-doing in our course. From our perspective, learning does not occur by passively receiving information given from outside. Instead, the learner is an active participant who learns by comparing the new to existing conceptions and experiences. We also wanted to apply the idea of inquiry-based learning 
in a technologically advanced environment: if literature lives in a symbiosis with media and, in particular, information networks, isn't it also important that learners study it in an authentic learning environment? Our teaching experiment was essentially about putting this insight into practice. The new learning environments also challenge the ideas of where and how learning occurs. As the ubiquity of technology grows, the pen and paper are gaining competitors that must be taken into account in learning situations. Young people can use technology in their free time, but applying it to learning situations is a new challenge for both teachers and students. Modern literature is far from being the only theme that requires language and literature teachers to take a stand on how to integrate a pedagogical approach that emphasises students' active participation with technology-enabled learning environments (e.g. Cope \& Kalantzis 2009).

In designing teaching, one should take into account the nature of the phenomenon to be taught, students' backgrounds and preliminary data, and the teaching objectives. Based on these premises, we formed the principal theme and objective of our modern literature course for international students learning Finnish: make the students' conception of literature as a unified entity collide with the reality of what modern literature can, in fact, be.

Using blogging as the pedagogical medium for teaching modern Finnish literature, in particular, was justified, because book blogs are a typical component of Finland's literary landscape. Even though the internet has not yet become a dominant publishing channel for literature, the technological revolution is visible precisely in the changed environment of how literature is received. Discussion forums, blogs and social media have brought a new, interactive dimension to literary publicity. In the $2010 \mathrm{~s}$, literature is discussed online (Niemi-Pynttäri 2013). There are about 150 active book blogs in Finland, with tens of thousands of monthly readers (Jalkanen \& Pudas 2013). Blogs are written by both authors and readers. In their blogs, authors discuss their life and work, and literary criticism, after having almost totally disappeared from print media, lives and flourishes in readers' blogs. Heated literature debates are an essential feature of these blogs. The blogs not only help overwhelmed readers navigate the vast amount of available books but they also offer new forms of commentary and 
activities promoting reading (Jalkanen \& Pudas 2013; Niemi-Pynttäri 2013). This is the culture of literary discussion we aimed to introduce to our students through the course.

\section{Implementing the teaching experiment}

Our aim in the course was not to offer a ready-made explanation or model of what modern literature is. Instead, the starting point was the idea emphasised in, for example, a new publication on literary history (Hallila et al. 2013), which suggests the field of modern literature is so fragmented that creating a holistic picture of it is not possible. We also applied Hallila et al.'s (2013) notion of how to create an idea of modern literature: analyse its individual elements, different works, themes and phenomena, and then try to form a holistic picture.

This approach to modern literature optimally suited our pedagogical thinking. Throughout the course, the emphasis was on understanding students as active participants who learn by reflecting on the new ideas they encounter and comparing them to existing conceptions and their own experiences. We chose independent blogging as the main working method because it supported our idea of modern literature and meaningful learning.

In this section we describe the progress of blogging based on the model of inquiry-based learning. Inquiry-based learning is a pedagogical model according to which the acquisition and adoption of new knowledge is most efficient when the learning process imitates the process of scientific research. This view is based on the idea that learning is a constructive process which, in a cognitive sense, strongly resembles the research process. Correspondingly, the research process can be understood as a learning process for the researcher and the academic community. (See also: Hakkarainen, Bollström-Huttunen, Pyysalo \& Lonka 2005; Hakkarainen, Lonka \& Lipponen 2005; Tynjälä 2004).

An essential element of the inquiry-based learning process is students' role as active participants and so-called shared expertise. Students become a sort of 
research group that jointly looks for a solution to a meaningful research problem. New knowledge on the topic is collaboratively constructed in the group, but data is also searched for individually - or as in our case, in pairs.

The model of inquiry-based learning optimally suits a study in which the aim is to understand a relatively ambiguous phenomenon (Hakkarainen, Lonka \& Lipponen 2005). In the case of this teaching experiment, the multifaceted phenomenon of modern literature required an innovative pedagogical method.

Figure 1. Blogging as a learning process

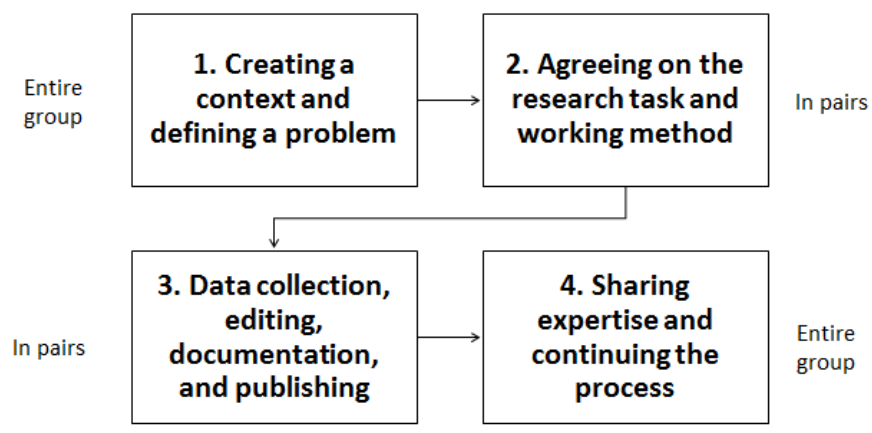

We analyse blogging in the modern literature course through four perspectives loosely based on the stages of inquiry-based learning. These perspectives are (1) creating a context and defining a problem, (2) agreeing on the research task and working method, (3) data collection, editing, documentation, and publishing, and (4) sharing expertise and continuing the process (see Figure 1). Stage 1 is about defining the assignment, in which both teachers and students participate. Students' independent activities start at Stage 2.

\subsection{Defining the assignment (stage 1)}

The planning and implementation of the course began by mapping what students already knew about modern Finnish literature and what they found interesting and perhaps strange in it. 
The participants' preconceptions were analysed based on essays titled 'Literature and Me', which were a part of the course application. The applicants wrote these essays in their own countries and attached them to the applications. The essays provided advance information as to what Finnish literature courses they had potentially attended, what Finnish literature they had read, and what they knew about the history and present state of Finnish literature. It was also essential to find out what the students wanted to know about Finnish literature.

We approached the essays through a number of questions, such as the following: What do the students write about when they are assigned to write about literature? What is the students' conception of modern literature like? What kind of a personal relationship with literature do the students have?

The course began with a joint introductory lecture intended to make the students realise how they could broaden their way of structuring the characteristics of modern literature. At the beginning of this lecture, the teacher summarised based on the pre-assignment and the initial interviews - the aspects that the participants were already familiar with, for example, the history of Finnish literature and the great significance of Finnish-language literature in the history of Finland. Then she highlighted some seemingly paradoxical features that the students had mentioned, for example, that modern literature is "gloomy and difficult" and contains "original humour".

The next step - in compliance with the model of inquiry-based learning - was to make the new information conflict with existing conceptions. The students were told about, for instance, the different roles writers have in modern Finland and that the traditional conception of literature based on a uniform national culture has reached the end of its road in the country (Jokinen 2013).

The key issues of modern literature were illustrated through cases and personal examples on such themes as how the boundary between so-called low and high literature has been erased and the co-existence, alongside the realistic narrative, of the fantasy narrative and poetry that searches for the limits of literature in the information network (Hallila et al. 2013). 
In the first meeting, the idea of the course was explained explicitly: owing to the manifold characteristics of modern literature and the transformation that literary culture has experienced, the main focus in this course would not be on studying writers' names, works or styles in the way the students might have expected. Their accustomed study methods would probably also change, because the aim was not to study the characteristics of literature or texts as such but to personally observe and reflect on phenomena in modern literature.

The course assignment - blogging in pairs, or co-blogging - was next presented to the participants. The assignment provided them with the opportunity to explore any phenomena related to modern Finnish literature and to write on it in the course blog collaboratively with another participant. We discussed with the students how a blog post, in addition to text, includes images, videos, links and colours, and challenged everyone to choose a research question that genuinely engaged them.

At this stage, the expectations for the blogging were defined. It was not important that the students produce some specific output or answer to a question. Instead, the aim was for each pair to produce at least three texts about the process stages for the course blog (see instructions for the blog task, Appendix 1).

It was emphasised that the text should be an online one and not written in a traditional research format. A number of important elements were highlighted: (a) their own independent thinking and personal experiences, (b) multifaceted utilisation of different textual resources (including image and video material) and online resources, and (c) consideration of interaction and the recipient. The blog's primary target group was identified as students in this course and other international learners of Finnish interested in Finnish literature. The students could thus design their blog projects rather freely. Blog posts were made in the joint lessons and marked in the course programme approximately every other day. In addition, the participants were expected to contribute to the assignment in their free time. Finally, the pairs presented their projects on the last day of the course. 


\subsection{The blogging process (stages 2-4)}

\subsubsection{Stage 2}

The second essential stage of the learning process in blogging included agreeing on the research task and creating a working method. The course's open-ended instructions provided students with the opportunity to implement the blogs in different ways. At this stage, students themselves became responsible for the activities: the rather loose assignment gave them the freedom but also the responsibility to think about the studied phenomenon itself - modern literature - and to choose an authentic problem or perspective that they found meaningful to explore.

For the blogging activity, this stage was significant. This was when the students began to choose their topics and discuss their conceptions of literature with people whose reading history differed from theirs. The pairs were formed and preliminary topics chosen at the beginning of the course, after the introductory lecture. Thereafter, the students began to plan their working schedules and create ideas for the content of their blogs.

The students could form pairs based on their own interests. The only restriction was that the partners should not have the same mother tongue, thereby ensuring that they spoke as much Finnish as possible at the different stages of the working process. Topic choice was also free, which resulted in a range of topics, from poetry slams as a phenomenon to detailed analyses of fictional texts.

In practice, as the students further specified their topic, they also discussed their conceptions of literature and starting points. Because the pairs themselves defined the assignment for their blog project, they also had to define the focus of their study, the implementation of the research and working processes, and the target of their work. Choosing the approach and writing style provided interesting insights on the learning process. Students had to agree on many points, for example, what to address or start with - the genre, a specific writer, an institution or something else. The writing also required agreement on aspects 
such as what style the blog was to be written in. Although online digital writing offers great potential for bloggers to have their voices heard, working in pairs meant a negotiation of what one's own voice is.

\subsubsection{Stage 3}

At Stage 3, students carried out the actual research, in other words, material collection, editing, documentation, and publishing. An essential feature of the blogging, however, was constant movement between the stages. In the same way, shared expertise was present throughout the process. After having defined the assignment for themselves, the pairs started to search for information on the internet and in books. Questionnaires, internet inquiries and interviews with Finnish people and foreigners were other important methods for collecting data. Interviews were filmed with mobile devices and edited to suit the blog posts. The visual material also included photographs taken by the students or found on the internet. Material was collected using a number of different channels.

An essential feature of the working process, however, was that the stages of the study occurred in parallel. The research problem was processed constantly, and for each pair, the essence was specifically what was done around the theme, not what was achieved. The final product in the blogging differed in an essential way from writing a traditional final report, though, because in such reports the work process usually remains invisible.

The students worked on the blogs for about three weeks, and the process could be described and documented from the beginning. All the stages of the learning process were shared between the members of the learning community. Through the students' reciprocal interaction, everyone's competence could be utilised to enhance the research process.

\subsubsection{Stage 4}

At Stage 4, the focus was on sharing expertise and continuing the process. It was essential to note that in blogging, the last stage of the inquiry-based learning 
process - the publication of results - was not the final step of the process. Instead, publishing the results of the substages was part of the blogging. Nevertheless, it was important to provide a joint opportunity for sharing expertise and returning to the research task given at the beginning of the course. After publishing the texts, the students presented their blogs orally and were given feedback by peers and teachers. However, the working process continued in various ways, especially for some pairs, and may still continue.

In this process, the aim went beyond publishing research results, and they were not the main criteria in evaluating the project's success. It was crucial, instead, to examine the results in relation to the common problem and to reflect on learning (Figure 2).

Figure 2. Blogging as a learning process: activities at the various stages
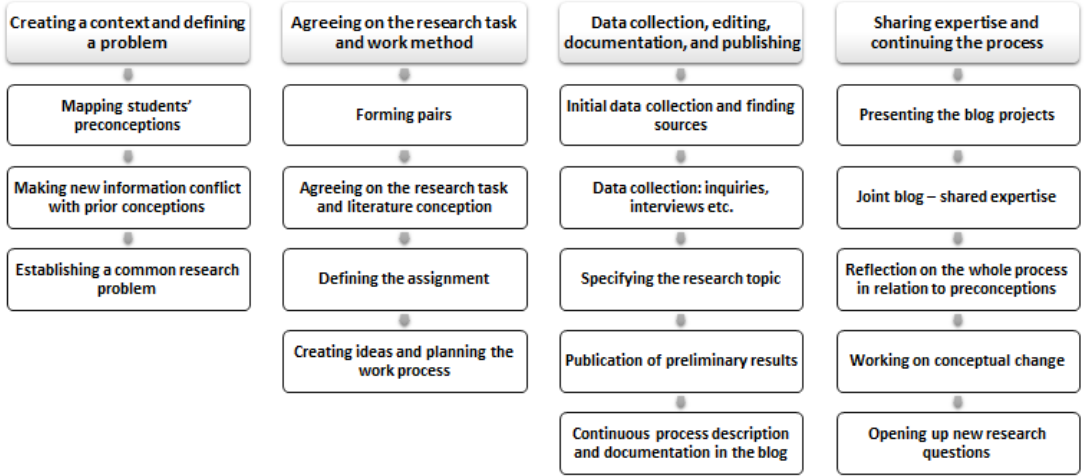

\section{Student blogs: three cases}

In the following sections, we analyse three cases that represent different ways of carrying out the blogging. In practice, we describe the activities of each pair at Stages 2 to 4 . 


\subsection{Pair 1: blogging as social activity}

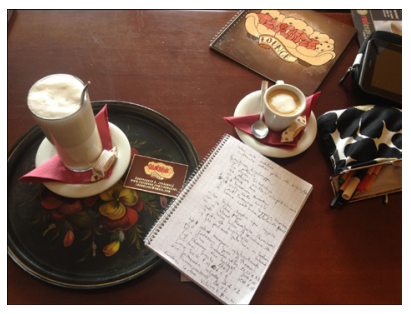

"It's raining. We are sitting in the best cafe in Jyväskylä. We found the cafe, called Lounge, near the university. Here you can drink a perfect espresso and chai latte, and the prices are also friendly. Just like the cafe's cute barista boy. We visited this cafe looking for inspiration, and we found it. There is an old second-hand bookshop next to the cafe, and even at the coffee table we can smell old books through the wall. Suddenly we knew what we should write about. We saw a small, old copy of The Unknown Soldier in the bookshop window.

We were taught at the university that all Finns have read those great classics. Have Finns really read them? If yes, did they read them only because they had to? Do even adults want to read them? Or do they all just read modern literature?

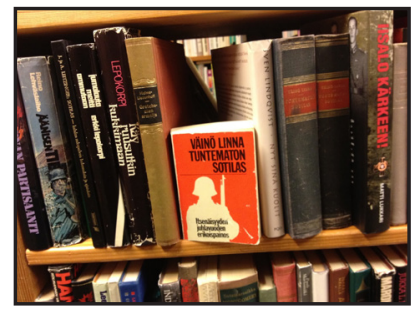

We'd like to look into this topic a bit, and we should find the best experts. We're planning to go to second-hand bookshops and Suomalainen Kirjakauppa ('The Finnish Bookshop', a national chain of bookshops) in Jyväskylä and ask the shop assistants what their experiences are. Then we can ask young Finns what they read" (Translated Blog text entry 19 August $2013^{3}$ ).

\subsubsection{Agreeing on the research task and working method}

Anna and Kata did not know each other at all before their team work began. However, guided by their shared interests, they decided to form a team. They

3. Photos taken by Anna and Kata, reproduced with kind permissions of the authors. 
chose a cafe in which they could more closely discuss the topic they wanted to choose for their blog. Their personal experience - the cafe, the smells and the barista - were described at the beginning of the blog as the starting point for their work. Anna had been blogging before and thus knew the features of its style. A beginning like this is characteristic of blogs. The most typical blogs are internet diaries in which individuals or groups focus on a specific theme. Here, as Anna and Kata openly reflected on their research problem, they arrived at their theme: they wanted to test and question the truthfulness of what they had been taught about Finnish literature.

In this pair's first blog post, there was a conflict between the past and the present: the modern reality of the cafe was contrasted with the second-hand bookshop full of old books. In addition, what had been learned at the home university and the truth about the present state of affairs collided with each other. Through their study, the students later revealed the present state of affairs. The post also described the students' working process as they planned their activities, that is, whom they needed to approach in order to find answers to their research problem.

\subsubsection{Data collection, editing, documentation, and publishing}

This blogger pair's second post also began with a personal approach - the authors retained their chosen blogging style:

"The sun is shining outside. At last. But we are again sitting in the same cafe after a hard day of work. The smell of coffee gives you new energy. Our notes are on the table together with the small The Unknown Soldier" (Translated Totta ja tarua blog entry, 23 August 2013).

The bloggers continued their post by discussing their interview with the secondhand bookshop keeper. An answer to the research question was part of the blog text and personal story of the interviewee:

"He also told us about his own experiences. We wanted to know if he had read, for example, The Unknown Soldier. He said he had read all 
the Finnish classics, but only at school, when it was compulsory. Maybe he would like to read some of them again when he gets a little older or middle-aged, but it does not feel like that yet. However, he said that many people buy all the old classics because they should have them on their bookshelves [emphasis added]" (Translated Totta ja tarua blog entry, 23 August 2013).

Here was one answer to the pair's research question: classics have been read at school because it was required, and Finns buy classics to have them on their bookshelves, not to read them. The students did not point at their results nor tell the reader they had found at least partial answers to their research questions. Instead, the answers were embedded in a light and chatty blogging style.

Data collection continued in the pair's third post, titled 'The Unknown Soldier is rather unknown'. In it, the students described a visit to the Suomalainen kirjakauppa bookshop in their search for the classics of Finnish literature.

"With the help of the Top10 list, we easily familiarised ourselves with new books, but we also wanted to look for classics. Even after ten minutes, we found nothing by Väinö Linna [the author of The Unknown Soldier]; we were almost certain that no classics were even sold here. Fortunately a friendly shop assistant asked if any help was needed. He showed us where the works of Linna, Waltari and Kivi were. But there weren't many, only two or three copies. Compared to this, contemporary literature sells rather well, because about 30 copies of [Sofi] Oksanen's new book were found. There were even two versions of it, a basic one for 30 euro and a deluxe edition 50 euro" (Translated Totta ja tarua blog entry, 27 August 2013).

The pair found individual copies of classics at the bookshop only after a long search and with the help of a shop assistant. They stated that that it seems Finns really do not read their classics in the way the students had been taught. The student pair concluded the blog post by saying: "The Unknown Soldier was so difficult to find that if you want to buy it at Suomalainen Kirjakauppa, it may remain unknown forever". 
All the posts of this pair included photos taken by the students themselves to document their activities. They mostly described the second-hand bookshop, the cafe and the bookshop, which were the central scenes of the posts. The main research findings were presented, seemingly unnoticed, as headings for the posts: 1) The smell of books through the wall, 2) Classics to be put on the shelf, and 3) The Unknown Soldier is rather unknown.

In this team's work, data collection, editing, documentation, and publishing merged. In the blog, the pair described and documented the interviews and search for classics through the medium in which they published.

\subsubsection{Sharing expertise and continuing the process}

The students presented their blog in a joint course meeting. They emphasised that it was useful to work together with someone they did not know. However, blogging did not end with the presentation. After the course, Anna posted a link to their video for the course Facebook group. The video was not created by just one individual. First the pair asked various people - from the course as well as outsiders - to write on post-it notes nice wishes that they would say to other people. Then they brought the notes to the second-hand bookshop described at the beginning of their blog, filmed the entire process, and made a video of it. Finally they posted the video on YouTube and linked it to the course Facebook site. In this way, the video became a public text, able to be viewed and shared by many people.

This process of sharing shows how writing is by no means a solitary activity anymore. In this new mode of writing, multimodal text is created through social activities (e.g. post-it notes + taking them to the bookshop + video + video editing + linking the video to the group's website). In the 'new writing' (Jenkins et al. 2013), the emphasis is on technical and social skills combined with a creative approach and the willingness of authors to publish their texts.

Anna commented on the video by saying that it was produced in their free time, while studying Finnish. In such a comment, she distinguished between 
activities related to leisure and those related to studying. She was probably not used to integrating leisure writing and study writing. Despite her prior blogging experience, she continued to see video making as something different from socalled actual studying. In the blog-writing process, however, the boundaries between leisure time and learning are erased and daily activities are incorporated into learning.

Overall, this pair's posts demonstrated how the bloggers worked seamlessly together and produced stylistically uniform text. Anna's conception of literature was traditional, but her conception of writing was modern - she was a skilled and experienced blogger able to create dialogue between the blog posts. Kata, on the other hand, had a more modern conception of literature but no experience of blogging. The conceptions of literature and writing collided with each other in a way that furthered the thinking of both of these learners.

During the process, the students modified the conception of literature they had adopted in their prior studies. Working on blogs included documenting the change that has occurred in their mindset. The old mental construction did not work because the modern Finnish conception of literature is, after all, not what they had previously learned and thought about it. Because the students had to broaden their view of the literary canon, a change in mindset occurred.

Characteristics of Anna and Kata's blogging:

- strong digital literacy (photography, making and posting videos on YouTube, editing, etc.);

- awareness of the text type used in blogs, experience of blogging;

- writing as a social activity, co-writing.

\subsection{Pair 2: writing a blog as a remixing of voices}

The first blog post of this student team, Anita and Veiko, began as follows:

"It surely did gripe us when we had to write a blog post on a Monday morning. But as we have to, so be it. It was you who wanted it!!! 
Nowadays everybody blogs, even writers - to mention an example, Jääskeläinen! They surely have forgotten what they should be doing, instead of sitting at the computer. Everything used to be clear - when you got a good idea, you took paper and a pen and wrote it down. Then you sent a letter to the newspaper agency, and the newspaper agency published it - so that everybody could read about it in the paper. But now everybody sits at the computer writing nonsense and publishing it, thinking that everybody will read what they've been writing. They surely do not read. Who in the world would manage to read all those blog posts? Nobody! Listen to me, you person - instead of sitting in front of the computer all evening and night long, you should be doing proper work. Our ancestors did real work ever since the Stone Age, and even the human body is used to it. Now the last couple of years it's been so that people just sit in front of the computer and move their fingers. So no wonder they've become weak and fat and don't even manage to do proper work. Especially young people are quite lost because of computers - they only laze around and loiter all the time" (Translated Totta ja tarua blog entry, 19 August 2013).

\subsubsection{Agreeing on the research task and work method}

Anita and Veiko knew each other from a previous Finnish course and formed a Hungarian-Estonian team, whose differences were related to their prior knowledge of Finnish literature. Anita was familiar with the classics and some modern literature, and she had already read books in Finnish. She had her own special perspective on Finnish literature: "A good thing about Finnish literature is that one can write about anything (immigrants, gay relationships, history, politics...) without having to be afraid of punishments from different parties or a negative reception from the audience". Veiko, on the other hand, had read Finnish literature in Estonian and wrote: "I still would like to know much more because I am really interested in Finnish culture as a whole".

Anita was also aware that by reading literature in the original language one can learn the language, develop one's own writing style and learn to know Finnish culture and "the soul of Finns". Besides, for her it was "a way of escaping 
everyday Hungarian life". The concept of soul was present in the excerpt, just like it is often highlighted in literary discussions with people from Eastern Europe. The concept is associated with classical literature analysis, and it can be connected to the cultural literacy mentioned earlier in this article. It was, indeed, interesting to see if the student would return to the concept later.

This blogger team shared an interest in societal affairs, and both of them were to some extent familiar with Tuomas Kyrö's bestseller Mielensäpahoittaja (translated as Griped by Douglas Robinson). Furthermore, they did not approach their topic too seriously but instead wanted to have fun. They were also interested in practising writing:

"Our aim is to investigate, through Tuomas Kyrö's bestseller, what gripes Finnish people. Tuomas Kyrö has already done great work and written about forty possible reasons. We want to continue Kyrö's work and ask ordinary Finns if they are also upset for the reasons Kyrö mentions. That is how we intend to find out how much the reasons invented by Kyrö are connected to reality, in other words, to Finns' everyday experiences" (Translated Totta ja tarua blog entry, 19 August 2013).

This team ideated and planned the work process thoroughly. Using ten of the forty reasons described by Kyrö for the grumpy old man to be griped, they created a statement-based questionnaire intended for the ordinary Finn. Respondents answered the ten statements (e.g. mailed advertisements) on a 5-point scale: $1=$ does not annoy or annoys only a little, 2 = annoys a little, $3=$ annoys to an average extent, $4=$ annoys a lot, $5=$ annoys thoroughly.

\subsubsection{Data collection, editing, documentation, and publishing}

In their data collection process, Anita and Veiko interviewed ten people on the streets of Jyväskylä. They found that four of these interviewees had not read Mielensäpahoittaja, which made the pair wonder about the cultural knowledge of the local people. They processed the responses to the questionnaire and stated that the reasons that upset the grumpy old man were similar to those that upset 
the people in Jyväskylä in general. The reason that received the highest score was jumping the queue. An essential characteristic of this blogger pair's text was remixing, in other words, combining and editing (Lankshear \& Knobel 2011). Anita and Veiko imitated Kyrö's style, beginning all their posts with the grumpy old man's signature phrase: "Kyllä minä niin mieleni pahoitin, kun..." (It surely did gripe me when...). They also imitated the writer's style but modified the reasons for being upset to suit their own daily lives, for example, "I surely would like to complain about Kata leaving the bar early last night" (Totta ja tarua blog, 23 August 2013).

In addition to a young student's perspective, the bloggers imitated Kyrö from the perspective of an imaginary old man: "There surely are too many choices today, and especially young people have too big dreams" (Totta ja tarua blog, 23 August 2013). The text received extra nuance from the continuously advancing language skills of the advanced learners of Finnish. Combining and editing different voices - polyphony - is a typical feature of postmodern literature.

This team went beyond polyphony, however, and actively utilised multimodality in their posts, including images found on the internet with their source information, a link to Kyrö's Facebook site, videos in which Kyrö reads his work, and remixed and edited images. This team made a picture collage in which they remixed images and text, placing the reader in the centre of activity. Different writers fight for the reader's time and interest, equipped with swords. On the left, two serious writers - the poet Olli-Pekka Tennilä and magical realism writer Pasi Jääskeläinen - call for the reader's attention, and on the right, the humorist Tuomas Kyrö. The students' knowledge of Finnish literature had grown, and they demonstrated it in a multimodal way, through images. They generated authorship by combining and editing existing artefacts in a creative way.

\subsubsection{Sharing expertise and continuing the process}

An analysis of the students' conceptions of literature clearly showed that Veiko's conception of Finnish literature had broadened. Together with his co-blogger, he had become able to sort modern Finnish writers into temporal and thematic 
categories. Anita's serious approach to literature, on the other hand, seemed to have become lighter - her earlier cultural literacy related to literature had been transformed, her reflections on the concept of the soul receded, and she was able to assume a playful attitude toward literature. A completely different approach joined her 'literature is the soul of a nation' thinking.

Characteristics of Anita and Veiko's blogging:

- the ability to produce multimodal text: editing and combining existing artefacts (images), that is, remixing;

- creativity, play and humour;

- breaking the boundaries between formal and fictive writing, innovative authorship.

\subsection{Pair 3: blogging as metadiscourse on literature}

An excerpt from the beginning of Giedre and Johanna's first blog post:

"Both of us are interested in literary metadiscourse, literary criticism, and we have also written reviews in journals. That's why we would now like to study how Finnish literary criticism is doing.

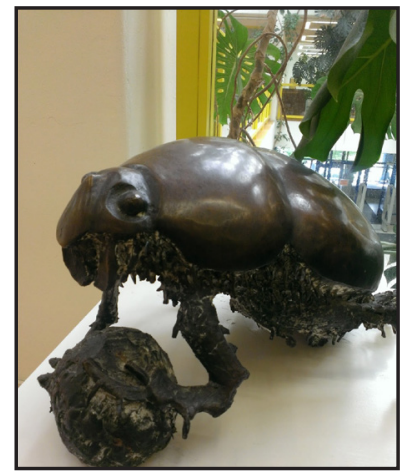

In her lecture, Elina told us that when studying literature one should also pay attention to the institution of literature. This institutionality is also important in criticism. Already at the turn of the millennium, people spoke about Finnish press criticism becoming more journalistic, in other words, more superficial (see e.g. Markku Ihonen's essay 'Mitä on hyvä kritiikki' [What is good criticism?, link included in original blog post]). But nowadays perhaps most criticism is not officially published in magazines but, instead, in blogs, where nobody edits the texts and people can write whatever. 
Or can they? To find out more on this, for our next post we decided to compare reviews of Kari Hotakainen's novel Juoksuhaudantie [The Trench Road] (2002) from official reviews and from blogs.

We chose this book because it is a recognised, provocative and modern work that has received important prizes" (Translated Totta ja tarua blog, 19 August 20134).

\subsubsection{Agreeing on the research task and work method}

Even the blog title, 'Discourse on metadiscourse', highlighted the bloggers' expertise in literary research. What the two bloggers - Johanna from Estonia and Giedre from Lithuania - had in common was expertise, the writing of literary reviews, and an inquiry-based approach to literature. The bloggers' own selfironic definition of themselves in the title, 'Johanna and Giedre LTD', portrayed them as competent content producers.

Johanna was writing her literature dissertation in Estonia. She had also studied literature outside of her home country and worked in literature-related museum and media positions. Giedre had studied in Finland for a year and was particularly interested in Finnish literature. She had completed various literature courses and studied both comparative literature and Finnish literature. Giedre had long been writing a fashion, style and culture blog in Lithuanian, so she was an experienced user of social media. Additionally, she wrote about music and had started to read modern fiction in Finnish as well.

These bloggers' research question focused on the relationship between official literary criticism and literature blogs. They chose Kari Hotakainen's novel Juoksuhaudantie [The Trench Road] as their example of Finnish literature. Their hypothesis was that literature blogs were simple and too personal, whereas literary reviews in newspapers and literary magazines were complex

4. A sculpture portraying a critic at the Jyväskylä University Library (Leena Turpeinen-Kitula: The Critic, 1975. Photo taken by Giedre; reproduced with kind permissions of the author. 
and impartial. They began to test their hypothesis using the means of literary research.

\subsubsection{Data collection, editing, documentation, and publishing}

The first reference in the bloggers' post told its own tale of expertise: the bloggers referred to literary researcher Markku Ihonen's essay 'Mitä on hyvä kritiikki' [What is good criticism?]. These kinds of references to literary researchers were not included in the blog texts examined earlier.

This blogger team formulated research questions that were used to search for certain features in reviews and literature blogs. The questions concerned the who, what, where, and central ideas of the material. They also considered whether or not the language in the book should be handled or why it might be interesting. Next the team created tables based on the four literary reviews and six literature blogs that were used. Finally, the research process was made transparent by the publication of the tables in their blog posts.

The bloggers used lots of images in their posts, ranging from ready-made internet stock photos and comics to the students' own photos. The ready-made online artefacts and self-produced ones formed a fluctuating whole. In addition to text, the students posted a screenshot of the literature blogs and reviews used as sources.

The visual element of the blog started with a photo of a sculpture called The Critic, which portrays a beetle rolling a ball of manure. The students also photographed their source materials, that is, the bound yearbooks of the Finnish literary magazine Parnasso.

An interesting feature of one blog post was the use of the hashtag (\#) with keywords:

\#Johanna\&GiedreOY \#nykykirjallisuus \#friikki \#löyly \#CIMO \#Anna Karenina \#Raskolnikov \#Juoksuhaudantie \#kotiäiti \#parnasso \#hipsterit (Totta ja tarua blog, 26 August 2013). 
The bloggers condensed their message and flagged it in the way they would on Twitter. Was this a new way of condensing? Was it a new form of language, \#Finnish? In any case, the authors emphasised their cooperation, which implied that their writing was a social activity. Moreover, they were creative, played with the language, and produced public text. In these aspects, the blog post displayed a number of essential features of the 'new writing' (see Jenkins et al. 2009; Kallionpää 2014a, 2014b).

The hypothesis the bloggers set for their research turned out to be wrong; in other words, their conception of literature changed. Based on their study, they concluded that some literature blogs were of a high level, and that language and style were considered in nearly all of them. Literary reviews in magazines, instead, were sometimes 'personal and chaotic'. The team further stated that good texts could be found from various sources and that the opinions of both bloggers and literary researchers should be taken into account in order to get to know a book. Johanna and Giedre adopted the conception of literature experts according to which literature can be discussed in relevant ways also by those outside of the literary elite. Since the 1990s, this issue has been a central one in literary research, namely, a debate about what high literature is and who is entitled to talk about it (Jokinen 2010).

\subsubsection{Sharing expertise and continuing the process}

The bloggers were familiar with the scientific research report genre and began to experiment with broadening it in their blog texts. The genre received new dimensions in the online environment, in this case at least by making the research process visible. Images and comics provided an ironic, playful perspective on the literary research process, however, without parodying the assignment. Publicity is also a new feature of literary research - formerly, scholarly texts were bound in leather covers and forgotten on library shelves. This blogger team explicitly highlighted the change that took place in their conception of literature.

Characteristics of Johanna and Giedre's blogging:

- creativity, play, humour, irony; 
- experimenting with a new form of expression, \#Finnish;

- self-direction and initiative: literary researchers conduct research because they are able to;

- both participants' conception of literature changes due to their research.

\section{Results and discussion}

Literature provides readers with a window to the textual culture it represents or to the cultural context in which it has been written. Reading modern Finnish literature constructs a mental picture of Finnish people and society in the minds of foreign language learners, in addition to profoundly developing their language skills and cultural literacy.

In the Finland of the 2010s, the cultural context of literature is strongly mediated: the sanctity of literature has been shaken, and a textual as well as technological transformation is affecting even the structures of the publishing industry. If students are to have a realistic picture of the cultural context of Finnish literature, the teaching of literature must cover the texts, images and media that are essential for modern culture.

Book blogs and other websites are presently the dominant channels of Finnish literature discussion. In our teaching experiment, we aimed to introduce students to this environment of literary debate and offer them an innovative opportunity to take possession of the field of modern literature.

The purpose of this article was to investigate what kinds of new dimensions blogging can add to second-language learning in the context of modern Finnish literature. We also wanted to find out how new learning environments and approaches can be applied to broaden the literature conception of students of Finnish as a second or foreign language. Our practical aim was to present a potential pedagogical solution to the following question: What should we talk about or teach when our mission is to deepen students' knowledge of Finnish contemporary literature in the 2000s? 
In this concluding section, we summarise our findings on how blogging supports the learning process by broadening the participants' conception of literature and enhancing their language skills.

\subsection{Characteristics and benefits of blogging}

The analysis of blogging as an activity shows that the working process includes various stages, during which students practise a range of skills in diverse ways, and their in-depth understanding of the phenomenon being taught increases. In creating multimodal texts, students disengage from the production of traditional, linear text, and it is clear that their conception of what a text is changes during this process. This implies that the production of text is interactive instead of being one-way, linear writing for the reader. Observations made at the various stages of the activities also show that it is not the final output that is significant in blogging (e.g. a traditional research report) but the shared learning process that, at its best, continues even after the learning event.

Students' blogging complies with the principles of new writing: existing artefacts (videos, digital texts, images, colours) are combined and edited (i.e. remixed) into a new format. New authorship self-consciously utilises creativity, play and humour. It also embeds new features into older text types, which may generate the text types of the future. For new authorship, it is important to experience one's own output as significant and to share it (Jenkins et al. 2013).

In the teaching experiment, we observed that the chosen working method and assignment motivate students to adopt an active role in their learning process. Agency activates students' thinking. At the same time that the assignment encourages active and independent agency, it also encourages independent thinking and new, creative solutions, which they experience as meaningful.

Language learners often remain even for long periods in a 'learner's niche', in which they are not in contact with the target-language community. Writing blogs facilitates participation: because blog texts are multimodal, readers pay more 
attention to the blog as a whole than to potential individual language errors. Bloggers have the opportunity to demonstrate their competence in various ways, not just by producing linear text.

Blogging shows that it is fruitful and mutually beneficial to integrate second or foreign language learning with the understanding and production of factual texts. Language need not - and actually should not - be taught separately from the context of the surrounding society and its texts. The integration of language and literature study is beneficial for the learner.

It is also worth emphasising that blogging provides an excellent language and culture learning opportunity even for students whose language skills are not of the same level. Our starting point was not to group students into pairs based on equal language skills levels. Instead, we let them form pairs taking into account all human dimensions, not just their level of language skills assessed through a specific method. This pair work succeeded excellently, and language proficiency was only one feature among many.

\subsection{Broadening the conception of literature}

Our study shows that blogging by applying the basic idea of inquiry-based learning suits the teaching of modern literature ideally: blogging allowed us to integrate pedagogical needs with the content.

Blogging is suitable for teaching modern literature in a cultural situation where literature education can no longer be based on the literary canon emphasised in traditional teaching. It is difficult to identify the canon of modern literature because, first, the identification of classics and their features would require distance from the era that is being evaluated. Second, the number of published books has exploded, and so many conceptions of literature exist side by side that reaching a consensus is impossible.

Therefore, when it comes to assigning value to literature, the present emphasis is on the view that the evaluation of artistic quality is relative, subjective and 
context dependent. In this sense subjective experientiality is the main element of quality measurement (Jokinen 2010). Literary discussion has, overall, become more democratic. It is natural that literature blogs are extremely popular in a time when an individual approach is appreciated - in both modern literature and blogs, room is given to deep, personal feelings.

Based on the pair work examples examined here, it can be stated that students' blog projects highlighted relevant perspectives on modern literature. The work process - particularly students' own digital writing - provided experiences of modern literature that could not have been conveyed through a teacher-centred approach.

An unexpected finding in our teaching experiment was that learning and the broadening of the conception of literature were visible, in addition to topic and perspective choices, also in the way students in the multimodal environment independently adopted the role of a modern writer and expressed in their blog texts (in a surprising way) the essence of modern literature.

The activities of the first blogger pair highlighted the social dimension of writing and the expansion of writing beyond digital texts and the so-called official teaching context. In contemporary writing, the process no longer ends when the text is etched on paper - its life continues in, for example, video format.

The role that the second pair of students adopted in relation to Tuomas Kyrö's Mielensäpahoittaja concretely manifests postmodern authorship: literature is intertextual, and every new voice is, in practice, a combination edited from different existing voices, which makes the result creative.

The third pair assumed a position on the way in which a new cultural situation generates new metadiscourse on literature. The handling of traditional literary criticism and digital texts side by side is an argument for the necessity to question established roles of discussing and assigning value to literature. In any case, we are facing a situation in which the old and new literary discourse 
can coexist: new features are embedded into older text types, which may generate new text types and forms of expression.

All the student pairs looked for and implemented new ways to discuss literature. The blog posts often focused on themselves, a typical approach for postmodern literature. They are self-conscious and interpret themselves, explaining 'what we wanted to say with this'.

The work of the student pairs also demonstrated in practice the break-up of the sanctity of literature: new authorship is based on creativity, play and humour - and, as a whole, does not take its role too seriously. The change in students' conception of literature became visible, above all, through the new ways of discussing literature that emerged in their blogs. This postmodern conception of literature, which highlights the features of the 'new writing,' clearly differs from the traditional idea of literature expressed in the preassignments.

Among various pedagogical methods, precisely blogging is exceptionally suitable for teaching modern literature because multimodal digital writing embodies, in an optimal way, the characteristics of postmodern literature. Based on the implementation and analysis of our pedagogical experiment in the modern literature course of CIMO, we found that it is pedagogically justified to use blogging to support second-language teaching. At its best, blogging is a method that opens up new learning environments and learning modes as well as helps broaden students' conception of literature. It seems particularly suitable for the examination of phenomena in modern literature.

\subsection{Critical reflection on the teaching experiment and its applicability}

Teachers should take into account that the 'new writing,' as part of new media literacies, is a challenge for teaching as well. They should discuss with students their conceptions of writing and start to practise and implement digital, multimodal texts: 'new writing'. These actions will inevitably lead to new questions, such as how to assess multimodal text produced with a peer. Because 
there are no ready-made assessment tools for these texts, teachers should agree on them together with students before they begin to write. This is a way of genuinely involving students in the entire writing process.

Even though this article focuses on the skills development of second-language learners, the process and results can be applied to any form of literature education, ranging from basic education to literature classes at general upper secondary school and comparative literature studies at universities.

\section{Acknowledgement}

This article has been translated from Finnish by Sirpa Vehviläinen.

\section{References}

Ahvenjärvi, K. \& Kirstinä L. 2013. Kirjallisuuden opetuksen käsikirja. Tietolipas 239. Helsinki: Finnish Literature Society.

Coiro, J., Knobel, M., Lankshear, C. \& Leu, D. (eds.). 2014. Handbook of research on new literacies. London: Routledge.

Cope, B. \& Kalantzis, M. 2009. Multiliteracies: new literacies, new learning. Pedagogies: An International Journal, 4 (3), 164-195. doi:10.1080/15544800903076044

Ekholm, K. \& Repo, Y. 2010. Kirja tienhaarassa vuonna 2020. Helsinki: Gaudeamus.

Hakulinen, A. Kivelä, R. \& Ranta, T. 2006. Lukiolaisen äidinkieli ja kirjallisuus. Helsinki: WSOY.

Hakkarainen, K., Bollström-Huttunen, M., Pyysalo, R. \& Lonka, K. 2005. Tutkiva oppiminen käytännössä. Matkaopas opettajille. Helsinki: WSOY.

Hakkarainen, K., Lonka, K. \& Lipponen, L. 2005. Tutkiva oppiminen. Järki, tunteet ja kulttuuri oppimisen sytyttäjinä. Helsinki: WSOY.

Hallila, M., Hosiaisluoma, Y., Karkulehto, S., Kirstinä, L. \& Ojajärvi, J. 2013. Suomen nykykirjallisuus 1-2. Helsinki: Finnish Literature Society.

Husson Isozaki, A. 2014. Flowing towards solutions: literature listening and L2 literacy. The Journal of Literature in Language Teaching, 3 (2). Retrieved from http:/liltsig.org/wpcontent/uploads/2014/12/LiLT-3_2-Isozaki.pdf 
Hvistendahl, R. E. 2000. "Så langt 'vår' diktning tenner sinn i brann. . ." En studie av fire minoritetsspråklige elevers arbeid med norsklitteratur fra perioden1860-1900. Acta humaniora 70. Oslo: University of Oslo.

Jalkanen, K. \& Pudas, H. 2013. Rivien välissä. Kirjablogikirja. Helsinki: Avain.

Jenkins, H., Clinton, K., Purushotma, R., Robison, A. J. \& Weigel, M. 2009. Confronting the challenges of participatory culture: media education for the 21st century. MacArthur Foundation.

Jenkins, H., Ford, S. \& Green, J. 2013. Spreadable Media. Creating value and meaning in a networked culture. New York: New York University Press.

Jokinen, E. 2010. Vallan kirjailijat. Valtion apurahoituksen merkitys kirjailijoille vuosituhannen vaihteen Suomessa. Helsinki: Avain.

Jokinen, E. 2013. Kirjailijoiden yhteiskunnallinen asema. In M. Hallila, Y. Hosiaisluoma, S. Karkulehto, L. Kirstinä \& J. Ojajärvi (eds.), Suomen nykykirjallisuus 2. Helsinki: Finnish Literature Society, 159-176.

Kallionpää, O. 2014a. Monilukutaidon opetus on ennen kaikkea uusien kirjoitustaitojen opetusta. Language, Education and Society e-journal. Retrieved from http://www. kieliverkosto.fi/journals/kieli-koulutus-ja-yhteiskunta-lokakuu-2014/

Kallionpää, O. 2014b. Mitä on uusi kirjoittaminen? Uusien mediakirjoitustaitojen merkitys. Media \& viestintä, 37 (4), 60-78. Retrieved from http://www.mediaviestinta.fi/arkisto/ index.php/mv/article/view/54/43

Lankshear, C. \& Knobel, M. 2011. New literacies: everyday practices and social learning (3rd ed.). Maidenhead: Open University Press.

Lehtonen, M. 2001. Post scriptum - Kirja medioitumisen aikakaudella. Tampere: Vastapaino.

Lounavaara, M.-T. 2004. Näytelmän lukupiiri suomi toisena kielenä-opetuksessa. Integraation tukeminen kaunokirjallisuuden avulla. Master's thesis in Finnish. Helsinki: University of Helsinki Department of Finnish.

Malm, R. 2006. Kirjallisuuden opettamisesta Vilnan yliopistossa - kun teoria ja käytäntö eivät kohtaa. In S. Pöyhönen \& K. Hiltula (eds.), Opettajana vieraalla maalla. Opetuskulttuurien kohtaamisia. Jyväskylä: University of Jyväskylä Centre for Applied Language Studies, 97-109.

Mela, M. \& Mikkonen, P. (eds.). 2007. Suomi kakkonen ja kirjallisuudenopetus. Tietolipas 216. Helsinki: Finnish Literature Society.

Myonghee, K. 2004. Literature discussions in adult L2 learning. Language and Education, 18 (2), 145-166. doi:10.1080/09500780408666872 
Niemi, J. 2010. Kaanon ja kirjallisuuden opetus 2000-luvulla. In S. Häppölä \& T. Peltonen (eds.), Kuutamokeikka ja muita teitä tekstien kiehtovaan maailmaan. Helsinki: Äidinkielen opettajain liitto, 45-55.

Niemi-Pynttäri, R. 2013. Verkkokirjallisuus hakee muotoaan. In M. Hallila, Y. Hosiaisluoma, S. Karkulehto, L. Kirstinä \& J. Ojajärvi (eds.). Suomen nykykirjallisuus 1. Helsinki: Finnish Literature Society, 349-363.

Parente-Čapková, V. 2009. Mietteitä kielestä, kirjallisuudesta, oppimisesta ja opettamisesta. In Vehkanen, M. (ed.), Karjalanpaistista kaksoiskonsonanttiin. Suomen kielen ja kulttuurin vaikuttajat maailmalla. Centre for International Mobility CIMO. Erweko, 197-202.

Perusopetuksen opetussuunnitelman perusteet 2014 [National core curriculum for basic education 2014]. Retrieved from http://www.oph.fi/download/163777_perusopetuksen opetussuunnitelman perusteet 2014.pdf

Rantala, T. 2006. Etnografisen tutkimuksen perusteet. In J. Metsämuuronen (ed.), Laadullisen tutkimuksen käsikirja. Helsinki: International Methelp.

Saarinen, L., Joensuu, J. \& Koskimaa, R. (eds.). 2003. BOOK 2010. Development trends in the book trade - summary. Jyväskylä: University of Jyväskylä. Retrieved from http://urn. fi/URN:ISBN:951-39-1559-X

Smolander, J. 2012. Runoja ja merkityksiä: runous lukion suomi toisena kielenä -opetuksessa. Master's thesis. Jyväskylä. Retrieved from http://urn.fi/ URN:NBN:fi:jyu-201202011111

Staršova, T. 2007. Kirjallisuuden opetuksesta Petroskoin valtionyliopiston itämerensuomalaisten kielten ja kulttuurin tiedekunnassa. In M. Mela \& P. Mikkonen (eds.), Suomi kakkonen ja kirjallisuuden opetus. Helsinki: Suomalaisen Kirjallisuuden Seura.

The Finnish Book Publishers Association. 2015. Statistics. Retrieved from http://www. kustantajat.fi/pages/k9/tilastot/

Taipale, S. 2013. The affordances of reading/writing on paper and digitally in Finland. Telematics and Informatics, 31 (4), 532-542. doi:10.1016/j.tele.2013.11.003

Tynjälä, P. 2004. Oppiminen tiedon rakentamisena: konstruktivistisen oppimiskäsityksen perusteita. Helsinki: Kirjayhtymä.

Vaarala, H. 2009. Oudosta omaksi. Miten suomenoppijat keskustelevat nykynovellista? [From strange to familiar: how do learners of Finnish discuss the modern short story?] Doctoral dissertation. Jyväskylä: Jyväskylä studies in humanities 129. Retrieved from https://jyx. jyu.fi/dspace/bitstream/handle/123456789/22654/9789513937737.pdf?sequence=1 


\section{Website}

Totta ja tarua blog http://tosijataru.blogspot.fi

\section{Appendix 1. Student assignment}

Assignment. Modern Finnish literature is a broad concept. It is said that the literary field is fragmented, in other words, broken into small parts. That's why we cannot define modern Finnish literature in just a sentence or two. So, if you want to get an idea of modern literature, the best way is to analyse its individual parts, different works, themes and phenomena, and then try to form an overall picture based on them.

In this course, together with another course participant, you will choose a phenomenon in modern Finnish literature that interests you. Then you will look for information on this topic and write about your thoughts and experiences in the course blog. (Blogs naturally also include images, videos, links, etc., in addition to text.) In the course blog, you can follow and comment on the other pairs' blog texts, which will complement your overall idea of modern literature.

Choosing a topic. Find an interesting perspective that you want to share with the others. You can focus on an individual book or writer, but first discuss from which perspective you will explore the topic. You can also find new books at the course library.

The topic can be any phenomenon related to literature:

- Translating literature, e-books, literary prizes, writer blogs, writers from Jyväskylä...

- A good start could be to define a research question on the topic and then look for an answer to it. For example: What do Finns read? How are books advertised in Finland? 
- How has Harjukaupungin salakäytävät/book X been handled in literature blogs?

Blog posts are made in the joint lessons, but it's good to prepare them also in your free time. Supervised work on the blogs is arranged about every two days. The pairs are formed and topics chosen on Wednesday 14 August and Thursday 15 August. After that you can independently schedule your work and start to create ideas for the blog content.

Blog posts. Every pair produces at least three blog posts and comments on at least three other posts. If you get a comment, it's naturally nice if you also respond to it.

In your first post (written during the first week), you present your topic and explain why you are interested in it.

In your second post (written during the second week), you report on the progress of your research project and how you've been looking for an answer to your question. What have you discovered on the topic? Has something unexpected happened during your journey?

In your third post (written at the beginning of the third week), you share what you have discovered on the topic and what thoughts working on the topic has evoked in you.

\section{Things to remember when writing the blogs:}

- a fresh and personal viewpoint (your own thinking and personal experiences);

- the utilisation of text, images, video material, etc. and their suitability for the blog as a whole;

- an interactive approach, i.e. how the recipient has been considered. 


\section{Also remember:}

The blog's primary target group consists of students in this course and other international learners of Finnish interested in Finnish literature.

However, remember that the blog is public and accessible for anyone, so you should choose the content accordingly. When you attach photos and videos to the blog, always remember to ask for the permission of the people in them. If you copy an image from the internet, indicate the source.

All the student pairs will present their projects on the last day of the course. 


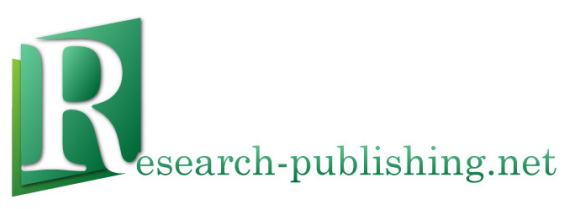

Published by Research-publishing.net, not-for-profit association Dublin, Ireland; Voillans, France, info@research-publishing.net

(C) 2015 by Research-publishing.net (collective work)

Each author retains their own copyright

Voices of pedagogical development - Expanding, enhancing and exploring higher education language learning Edited by Juha Jalkanen, Elina Jokinen, \& Peppi Taalas

Rights: All articles in this collection are published under the Attribution-NonCommercial -NoDerivatives 4.0 International (CC BY-NC-ND 4.0) licence. Under this licence, the contents are freely available online (as PDF files) for anybody to read, download, copy, and redistribute provided that the author(s), editorial team, and publisher are properly cited. Commercial use and derivative works are, however, not permitted.

\section{()ㅛ $\Theta \Theta$}

Disclaimer: Research-publishing.net does not take any responsibility for the content of the pages written by the authors of this book. The authors have recognised that the work described was not published before, or that it is not under consideration for publication elsewhere. While the information in this book are believed to be true and accurate on the date of its going to press, neither the editorial team, nor the publisher can accept any legal responsibility for any errors or omissions that may be made. The publisher makes no warranty, expressed or implied, with respect to the material contained herein. While Research-publishing.net is committed to publishing works of integrity, the words are the authors' alone.

Trademark notice: Product or corporate names may be trademarks or registered trademarks, and are used only for identification and explanation without intent to infringe.

Copyrighted material: Every effort has been made by the editorial team to trace copyright holders and to obtain their permission for the use of copyrighted material in this book. In the event of errors or omissions, please notify the publisher of any corrections that will need to be incorporated in future editions of this book.

Typeset by Research-publishing.net

Cover design by (C) Antti Myöhänen

ISBN13: 978-1-908416-25-4 (Paperback - Print on demand, black and white)

Print on demand technology is a high-quality, innovative and ecological printing method, with which the book is never 'out of stock' or 'out of print'.

ISBN13: 978-1-908416-26-1 (Ebook, PDF, colour)

ISBN13: 978-1-908416-27-8 (Ebook, EPUB, colour)

Legal deposit, Ireland: The National Library of Ireland, The Library of Trinity College, The Library of the University of Limerick, The Library of Dublin City University, The Library of NUI Cork, The Library of NUI Maynooth, The Library of University College Dublin, The Library of NUI Galway.

Legal deposit, United Kingdom: The British Library.

British Library Cataloguing-in-Publication Data.

A cataloguing record for this book is available from the British Library.

Legal deposit, France: Bibliothèque Nationale de France - Dépôt légal: septembre 2015. 